
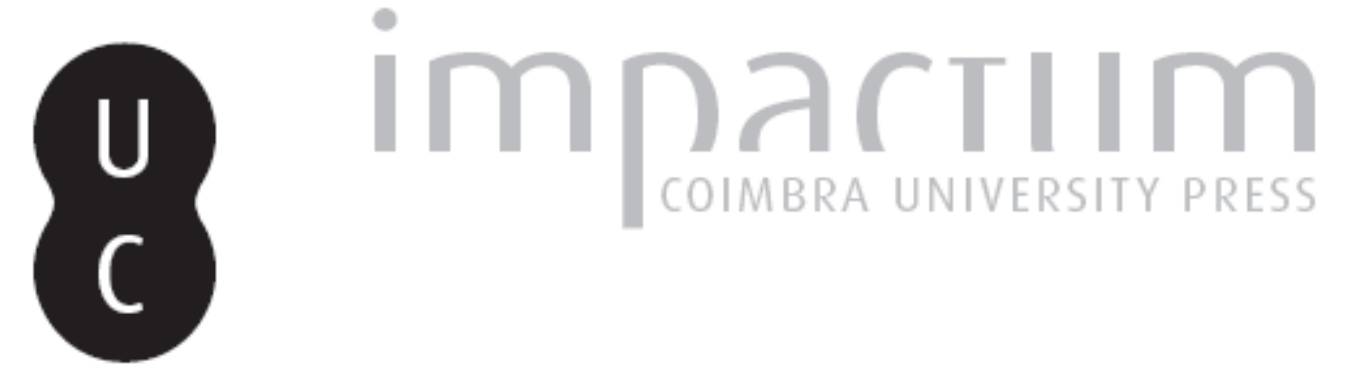

\title{
The studio in the School of Architecture and Urban Design of the University of São Paulo: the 1962 reform and its contemporary issues
}

Autor(es): $\quad$ Pereira, Juliano Aparecido

Publicado por: Editorial do Departamento de Arquitetura

URL persistente:

URI:http://hdl.handle.net/10316.2/37293

DOI:

DOI:http://dx.doi.org/10.14195/1647-8681_4_36

Accessed : $\quad$ 26-Apr-2023 11:59:24

A navegação consulta e descarregamento dos títulos inseridos nas Bibliotecas Digitais UC Digitalis, UC Pombalina e UC Impactum, pressupõem a aceitação plena e sem reservas dos Termos e Condições de Uso destas Bibliotecas Digitais, disponíveis em https://digitalis.uc.pt/pt-pt/termos.

Conforme exposto nos referidos Termos e Condições de Uso, o descarregamento de títulos de acesso restrito requer uma licença válida de autorização devendo o utilizador aceder ao(s) documento(s) a partir de um endereço de IP da instituição detentora da supramencionada licença.

Ao utilizador é apenas permitido o descarregamento para uso pessoal, pelo que o emprego do(s) título(s) descarregado(s) para outro fim, designadamente comercial, carece de autorização do respetivo autor ou editor da obra.

Na medida em que todas as obras da UC Digitalis se encontram protegidas pelo Código do Direito de Autor e Direitos Conexos e demais legislação aplicável, toda a cópia, parcial ou total, deste documento, nos casos em que é legalmente admitida, deverá conter ou fazer-se acompanhar por este aviso.

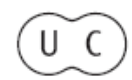




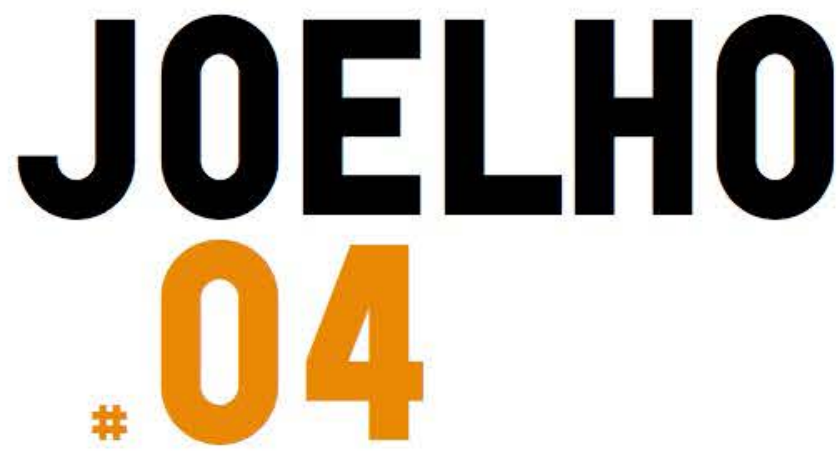

\section{ENSINAR PELO PROJETO \\ TEACHING THROUGH DESIGN}

\section{Coordenaçẫo:}

Paulo Providência

Gonçalo Canto Moniz

Alexandre Alves Costa Juan Domingo Santos Florian Beigel Philip Christou Elizabeth Hatz David Leatherbarrow Andrew Clancy Colm Moore Michael McGarry Willemijn Wilms Floet

Exposição TAPE 20Ir-12 


\section{Juliano Aparecido Pereira 'T'he studio in the School of Architecture and Urban Design of the University of Sao Paulo: the 1962 Reform and its contemporary issues}

This communication results from my doctoral research finished in 2009 , and is also a part of researches I intend to develop related to the teaching of project design.

The graduate course for architects at the University of São Paulo was created as an autonomous school in 1948, named as the School of Architecture and Urban Design. It was one of the first courses of its kind in Brazil. It was constituted from a faculty whose majority was aligned with modern Brazilian architectural thought, distancing itself from the traditional teaching methods of the School of Fine Arts or from the formation of the engineer-architect of the Polytechnics.

During its structuring, since 1948, and starting from a discussion process undertaken by its faculty, from 1962 onwards, a curricular reform was implemented in which is adopted the idea of the studio as the centre of the architect's formation and as a privileged moment of convergence of all learning acquired in the other courses.

Beyond the centrality of the studio, the 1962 Reform - as it became known - also proposes a new structure for the School itself, which is, from then on, organized into four Departments: 1. Project Department; 2. History Department; 3. Applied Sciences Department; and, 4. Technical Courses.

Among these four new departments, we will focus on the first one, that is, the Project Department. It has as its motivation, from the aforementioned central structure of the studio, the project teaching comprising four different, but complementary, scales, which are: object, building, city, and visual design. To realize this intent within the new educational scheme, the Project Department was responsible for teaching four course axes, from the first to the last year of the program. These axes were named at the time as Sequences. They were thus structured as Project Sequence, Planning Sequence, Industrial Design Sequence, and Visual Communication Sequence.

Professor Lucio Grinover (2009), who actively participated in this process, initially as a student and later as a professor at FAU USP, from 1958 to the present day, during an interview for my doctoral research, elucidates this new project teaching structure, also defending the desire, at the time, of realizing a broader Project University which would superimpose over the limits of a School of Architecture and Urban Design (FAU). The term Project University is coined by Professor Grinover himself to express the intention that everything, independent of scale, could be the object of the architect's project before its production, be it industrialized or unique. Professor Lucio Grinover thus expresses his point of view:

This individual, when he left FAU USP, was one that could design in several areas, he would choose the area on which he would concentrate, and this is why there were the four sequences: Project, Industrial Design, Visual Communication, and Urban Design. FAU USP's idea was a little utopic, I agree, but I think that it is still an extremely valid idea even today, of practically having a Project University. This was my great dream as a boy, to be able to participate and collaborate in the creation of a Project University. (...). Okay, what mattered was having all teaching as basic, all the teaching development, be it theoretical or practical, in a project. ${ }^{1}$

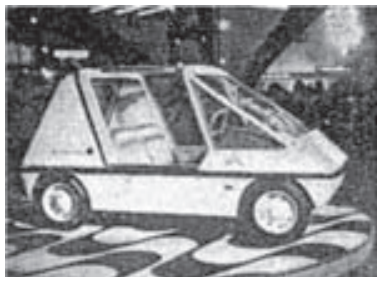

2. Car Aruanda, Antonio da Rocha. 
In this context, and differently from other schools of the same period, at FAU USP the option was not to form a specialist, for example, an architect and urban designer, or an object designer, or a graphic designer, as nowadays happens in Brazilian schools. The student was obliged to qualify and, in consequence, to grade, in all these areas, by mandatorily attending all project sequences: industrial design, visual design, building and urban design. After graduation, then as a professional, he would choose in which area he would like to develop his activities. The professional could then choose only one area in which to practice, but with a reflective vision of someone who considers all the other areas as a prerequisite for the determination and development of any project scale.

Within this teaching conception, that is, the idea of a Project University, basic knowledge would be inserted into the education in the four project sequences, in which each one would hold the introductory character for its learning. Let's examine, for example, the case of the Industrial Design Sequence. As per reports and document examination referring to education in this area, it was always considered important that the student should pass through an introductory character formation on representation and technical drawing at object scale, which has certain peculiarities in relation to drawing at building or urban planning scale. For materializing this education to students in those pioneer years, FAU USP established partnerships with the SENAI ${ }^{2}$ network, which provided, for the drawing classes at FAU USP, small models used for teaching mechanical drawing at SENAI.

In those pioneer years of Brazilian industrialization, during the 60's, in which FAU USP also considered industrial design within its objectives, in examining the School's proposal for a complete education that was to be conferred on the architect enabled to also act in the professional field of design, it is important to highlight two additional characteristics of the course.

One of them is with respect to the final year's dedication towards completion of a thesis project, on a theme, also at object scale, of the student's free choice, but accompanied by a teaching advisor:

The fourth year work has a thesis project character, in which, during its development, should be used all practical training and the sedimented technical-theoretical information of the first three years. It shall be developed in three stages: Information, Project, Presentation. Note: The results shall be submitted to the appreciation of the industry. (FAU USP, 1963).

This character conferred on the fourth year demonstrates that the formation of an industrial designer is not understood as secondary or as complementary within the School, since it involves the development of a project in the same manner as what is demanded by FAU USP for course conclusion, in both the architecture and the urban design fields.

Another issue is with respect to a double evaluation process for exercises, by both the faculty and by industry, as the above mentioned quote demonstrates relative to the project developed in the fourth year.
Professor Lucio Grinover, with respect to the above, of approximating FAU USP's architects' production to the Brazilian industry, in 1966, as first president of the $\mathrm{ABDI}^{3}$, presents an article on industrial design in a magazine directed at industries. It was published in the magazine O Dirigente Industrial (The Industrial Leader). In his article, Grinover calls attention from industrialists towards the necessity of thinking a Brazilian cultural design and incorporating it into our industrial production. To Grinover, this would be a way to avoid the continuous and uncontrolled importation of design, with its consequent evasion of financial resources, which, still according to Grinover, characterized the major part of the great Brazilian industrial development which the country traversed after the Second World War. In defending his point of view, Grinover reminds us that the country already had reached a capacity for producing its own industrial design, seeing that its merits had been recognized even overseas. To prove this theory, Lucio Grinover mentions two international prizes received by the Brazilian industrial design. The 1957 "Soft Couch" (1 Soft Couch, Sérgio Rodrigues), by architect Sergio Rodrigues, awarded in 1961 by the Concorso Internazionale del Mobile, in Cantu, Italy, and that was being produced and sold in Europe. The second example was the popular car Aruanda (2 Car Aruanda, Antonio da Rocha), by FAU USP's alumnus, architect Antonio da Rocha, winner of the Brazilian prize Lucio Meira in 1964, with an automobile design which is then produced by Fissore in Italy and lures visitors to the latest Turin Auto Show. In the same magazine, Dirigente Industrial, aiming at linking FAU USP's production to Brazilian industry, Grinover equates the School's architectural students' production to these two examples of Brazilian industrial design, award winners overseas. In one of the article's pages he publishes prototypes of home appliances and equipment for the construction industry, this last being wall panels with the hydraulics installed in their interior (3 Dirigente Industrial, Lucio Grinover). All these works are from FAU USP students, developed within their Industrial Design sequence, and they are thus presented by Grinover (1966, p.27): These products are just a small but eloquent sampling of the creative capacity of the University of Sao Paulo School of Architecture and Urban Design's young generation of designers.

The time span proposed for this work closes it in 1968, since it aims at examining a moment we consider as pioneering, due to the structuring and deployment of a new architectural education at FAU USP. As was said, the form with which FAU USP conjugates the teaching of architecture in its different scales of project intervention is unique in Brazil. And, as to its consequences, it's worth indicating two ulterior observations. The following decades, that is, from 1970 to present days, there was an enormous proliferation of new autonomously structured Architecture and Urban Design courses in Brazil. The educational model determined by FAU USP, within this study's time period, with respect to the centrality of the studio in relation to the other courses, unanimously served as a model for all other new Architecture and Urban Design courses from 1970 on, or for reformulations of some older courses. But as to the plural education of design, understanding the different scales as a professional

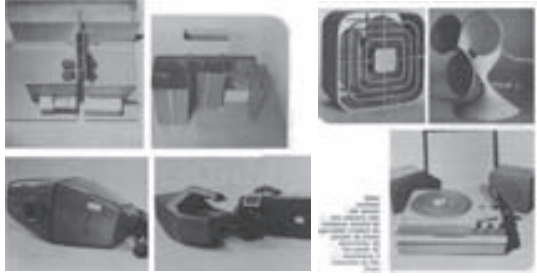

3. Dirigente Industrial, Lucio Grinover 
attribution of the architect, this principle was not adopted, which is evidenced by the numerous autonomous design courses which also emerged alongside in the country after the 1970's. The limit to this discussion proposed by FAU USP during those years, for integrating, within a single course, the education of the architect and of the designer, seems to have been placed by the School itself, when in 2006 it creates, parallel to its architecture and urban design course, another unique design course, with the possibility of a double practice: industrial design or visual design. In this context, FAU USP begins to form design professionals that are not architects, even though the educators, that is, the faculty, are, in their majority, architects. This marks a rupture with what was proposed in the 1962 Reform, even though some professors in their statements say that it is a design course that is in an architecture school and being taught by architects, a condition which would not fail to establish a transit and a complementarity between the different project scales.

Aiming at foreclosure of this article, in Brazil the separation between architecture and design schools has become more common, many times delimited and isolated, with autonomous discourses. On one side, we can consider this autonomy to be interesting, since it allowed a progress in specific knowledge. However, it has limited the dialogue between these complementary talents. Still, in the specific case of FAU USP, for its teaching tradition and of a few other schools, among these the School of Architecture and Urban Design, FAUeD UFU, where I currently teach, both undergraduate courses are offered: the formation of architects and urban designers and the formation of designers. In the aforementioned context, the linking of talents on the different project scales is maintained to an extent - however, no longer within the scope of future professional competencies which the student will receive, but within the scope of a critical and reflexive qualification scope, in which the architect and the designer may consider the necessary transit and complementarity among all the scales, from and towards the realization of their project activities.

To think these relations of complementarity in different project scales still seems to us an important and valid idea for the formation of the architect, in which the studio is still placed as a privileged space for teaching, information and formation. To finish and complement my exposition, I would like to quote the writer Italo Calvino (1990, p. 79), in an excerpt from As Cidades Invisíveis (The Invisible Cities):

Marco Polo describes a bridge, stone by stone.

- But which is the Stone that sustains the bridge? - asks Kublai Khan.

- The bridge is not sustained by this or the other stone, - answers Marco - but by the curve of the arch that they form.

- Kublai Khan remains in silence, reflecting. Then he adds:

-So why talk about the stones? Only the arch interests me.

Polo answers:

- Without stones the arch doesn't exist.

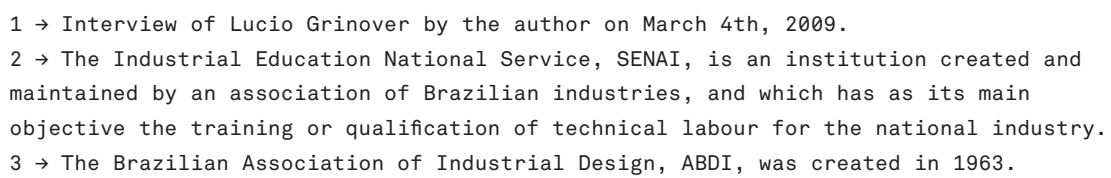

\section{Bibliographical References}

Calvino, I. (1990). As cidades invisiveis. São Paulo: Companhia das Letras.

FAU USP (1963). Desenho Industrial 1962 São Paulo: Project Department FAU USP.

Ficher, S. (1988). O Ensino da Construção no Domínio da Arquitetura. Projeto, 112, 129-130.

Ficher, S. (2005). Os Arquitetos da Poli: Ensino e Profissão em São Paulo. São Paulo: FAPESP, Edusp.
Grinover, L. (1966). Desenho atende ao mercado em termos de produção, O Dirigente Industrial,12, (7), Páginas 26 e 27.

Pereira, J. A. (2009). Desenho Industrial e Arquitetura no ensino da FAU USP. Doctoral Thesis. Sao Carlos: Department of Architecture and Urban Design at EESC-USP.

Produto e Linguagem (1965), 1.
Produto e Linguagem (1965), 2.

Produto e Linguagem (1965), 3.

Sinopses (1993). Memória. 